\title{
Sustained Virologic Response Rates of Direct Acting Antivirals in HIV Coinfected Hepatitis C Patients and Its Effect on Liver Fibrosis
}

\author{
Dora Lebron ${ }^{1}$, Alexandra Stang ${ }^{1}$, Alicia Lagasca ${ }^{1}$, Rabindra Ghimire ${ }^{1}$, Marysia Grzybowski ${ }^{2}$, Manal Elnabtity ${ }^{1}$, Ahmed Hamed ${ }^{3}$, Paul \\ Cook $^{1}$, Dawd Siraj ${ }^{4}$ \\ ${ }^{1}$ Division of Infectious Disease, Department of Internal Medicine, Brody School of Medicine at East Carolina University, Greenville, NC \\ ${ }^{2}$ Department of Public Health at East Carolina University, Greenville, NC \\ ${ }^{3}$ Department of Internal Medicine Brody School of Medicine at East Carolina University, Greenville, NC \\ ${ }^{4}$ Division of Infectious Diseases, Department of Internal Medicine, University of Wisconsin, Madison, WI
}

*Corresponding author: Dora Lebron, MD 2390 Hemby Lane Greenville, NC 27834, Division of Infectious Disease, Department of Internal Medicine, Brody School of Medicine at East Carolina University, Greenville, NC.

Received date: July 25, 2020; Accepted date: Augusł 26, 2020; Published date: August 31, 2020

Citation: Dora L, Alexandra S, Alicia L, Rabindra G, Marysia G, et all. (2020) Sustained Virologic Response Rates of Direct Acting Antivirals in HIV Coinfected Hepatitis C Patients and Its Effect on Liver Fibrosis. International Journal of Clinical Case Reports and Reviews, 3(2);

DOI:10.31579/2690-4861/036

Copyright: () 2020 Dora Lebron, This is an open access article distributed under the Creative Commons Attribution License, which permits unrestricted use, distribution, and reproduction in any medium, provided the original work is properly cited

\section{Abstract}

Background: Hepatitis C virus (HCV) is an important cause of chronic hepatitis with necroinflammation and fibrosis resulting in end stage liver disease and hepatocellular carcinoma. Direct acting antivirals (DAAs) are newer agents that directly interfere with the HCV lifecycle and result in high rates of sustained virologic response (SVR). We evaluated if treatment with DAAs in a real-world setting is as successful in HCV/HIV coinfected patients as it is in HCV monoinfected patients, and if some degree of fibrosis regression can be observed after completion of therapy in both groups.

Methods: We retrospectively reviewed data from HCV monoinfected and HCV/HIV coinfected patients who received treatment from 2014-2016 at the East Carolina University Infectious Diseases clinic. The primary outcome was to compare completion and sustained virologic response (SVR) rate at either 12 or 24 weeks between HCV monoinfected patients and HCV/HIV coinfected patients. The secondary outcome was to assess regression of fibrosis at either 12 or 24 weeks after completion of therapy, defined as one METAVIR stage improvement in their FibroSure ${ }^{\mathrm{TM}}$, a noninvasive biochemical test to estimate the stage of fibrosis.

Results: There were 41 patients in each group. Compared to the coinfected group, patient no show rate was higher in the monoinfected group ( $\mathrm{p}=0.0346)$. In the HCV monoinfected group, 25 (93\%) achieved either SVR 12 or 24. Two patients were non-compliant and had detectable viral load on evaluation at week 12. In the HCV/HIV coinfected group, 37 patients achieved SVR ( $\mathrm{p}=0.0039)$. One patient in the coinfected group didnot complete therapy but achieved SVR. In terms of fibrosis, 12/18 (67\%) in the monoinfected group demonstrated improvement in at least 1 Metavir stage and 6/18 (33\%) had no change. In the coinfected group, 8/16 (50\%) patients demonstrated an improvement in FibroSure ${ }^{\mathrm{TM}}$ stage, 5/16 (31\%) had no change, and 3/16 (19\%) had worsening fibrosis according to FibroSure ${ }^{\mathrm{TM}}$ stage, $(\mathrm{p}=0.4867)$.

Conclusions: In this small, real-world cohort, HCV/HIV coinfected patients treated with DAAs had higher completion and SVR rates than HCV monoinfected patients. Treatment failures in the monoinfected group were all linked to non-adherence, whereas, more coinfected patients achieved SVR, likely related to the fact that they were regularly engaged in routine HIV care. Fibrosis regression based on FibroSure ${ }^{\mathrm{TM}}$ was observed more in monoinfected patients than those with coinfection. Although not statistically significant, at least $50 \%$ of the patients in each group had regression of fibrosis.

Key Words: direct acting antivirals; fibrosure ${ }^{\mathrm{TM}}$; hepatitis $\mathrm{c}$ virus; human immunodeficiency virus; metavir; sustained virologic response

\section{Introduction}

Hepatitis $C$ virus (HCV) is a blood-borne virus that c hepatitis. Approximately 15-45\% of infected persons spontaneously clear the virus within 6 months.[1] People unable to clear the infection develop chronic hepatitis, characterized by necroinflammation accompanied by a variable degree of fibrosis, end stage liver disease, and hepatocellular carcinoma (HCC). It is estimated that 150 million people around the world have chronic HCV and the risk of developing cirrhosis in 20 years is around 15-30\%.[2] Chronic hepatitis $\mathrm{C}$ infection has been associated with

\section{SPACE}

mixed cryoglobulinemia, cryoglobulinemic vasculitis, B-cell non hodgkin lymphoma, SICCA syndrome, polyarteritis nodosa, monoclonal gammopathies, and immune thrombocytopenia. [3,4,5] Around $85 \%$ of patients with HCV will become chronically infected developing longterm complications associated with cirrhosis and extrahepatic manifestations representing a high economic burden.[6] In the United States, approximately $10 \%$ of the patients with Hepatitis C are coinfected with human immunodeficiency virus (HIV). HIV coinfected individuals are less likely to spontaneously clear the infection due to an impaired $\mathrm{T}$ 
cell response to HCV and are at higher risk to progress to cirrhosis with HIV viremia. This rapid progression may be attributable to weaker immune response against HCV, the effect of HIV on hepatic cells, and amplified microbial translocation accelerating fibrosis. [7, 8, 9] With the introduction of the direct acting antivirals (DAAs), a new era of hepatitis $\mathrm{C}$ treatment has emerged. Unlike interferon, DAAs interfere with various steps of the $\mathrm{HCV}$ lifecycle, similar to the way antiretroviral drugs work against HIV. [10] In HCV/HIV coinfected patients, treatment with pegylated-interferon based therapy was associated with lower sustained virologic response (SVR) rates, higher rate of adverse effects and drugdrug interactions when compared to monoinfected patients. [11, 12, 13] In this small real- world cohort, we compared treatment response in $\mathrm{HCV}$ monoinfected patients and HCV/HIV coinfected patients.

Changes in fibrosis after completion of therapy using the FibroSure ${ }^{\mathrm{TM}}$ stages were also evaluatedin both groups.

\section{Methods Study Design}

In this retrospective study, we reviewed the medical records of $82 \mathrm{HCV}$ monoinfected and $\mathrm{HCV} / \mathrm{HIV}$ coinfected patients presenting at East Carolina University Infectious Disease Clinic from January 2014 through December 2016. All patients were either treatment-naïve or treatmentexperienced with interferon $+/$ - ribavirin and at least 18 years of age. The Institutional Review Board approved all aspects of this study. Data collected included demographics (age, sex, and race), HIV status, and HCV genotypes. Laboratory values abstracted included alanine aminotransferase (ALT), platelet count, HCV ribonucleic acid (HCV RNA) at 4 weeks and 12 weeks of treatment, also at 12 or 24 weeks after completion of therapy. Among HIV-infected patients, CD4 and HIV viral load were measured. Treatment modalities, including type of DAA therapy and antiretroviral (ART) regimens were documented. Alcohol abstinence was a requirement to qualify for treatment.

The primary outcome was to compare completion rate and sustained virologic response at either 12 (SVR12) or 24 (SVR24) weeks after completion of therapy between HCV monoinfected and HCV/ HIV coinfected patients. The secondary outcome was to evaluate fibrosis regression and compare it between both groups using HCV FibroSure ${ }^{\mathrm{TM}}$ assay. This is a noninvasive biochemical test that measures liver fibrosis activity. The FibroSure ${ }^{\mathrm{TM}}$ results correspond to the METAVIR scoring system for stage of fibrosis. It is based on a 5-point scale from 0 to 4 for the stage of liver fibrosis. METAVIR classifications recorded were F0, no fibrosis/ F1, portal fibrosis without septa/ F2, portal fibrosis with few septa/ F3, numerous septa without cirrhosis/ F4, cirrhosis. Baseline fibrosis was determined and dichotomized ( $\leq \mathrm{F} 2$ for mild fibrosis and $\geq F 3$ for advanced fibrosis). FibroSure ${ }^{\mathrm{TM}}$ was obtained at baseline and either 12 or 24 weeks following treatment. Improvement in fibrosis was defined as one METAVIR stage improvement in FibroSure ${ }^{\mathrm{TM}}$ from baseline to 12 or 24 weeks after completion of therapy (FibroSure ${ }^{\mathrm{TM}}$ stage at baseline $(\mathrm{FB})-$ FibroSure $^{\mathrm{TM}}$ stage at SVR12 or $24($ FSVR $)=\operatorname{delta}(\Delta)$ FibroSure $^{\mathrm{TM}}$ stage). Changes in fibrosis were defined as: $(\Delta)$ FibroSure $^{\mathrm{TM}}$ stage $<0 \quad$ Part of the equation - continuity

- worsening fibrosis, $(\Delta)$ FibroSure ${ }^{\mathrm{TM}}$ stage $=0-0.5$ - no change and $(\Delta)$ FibroSure $^{\mathrm{TM}}$ stage $\geq 1$ - improvement).

\section{Statistical Analysis}

Chi square test and Fisher's Exact Test were used for categorical variables and to determine statistical significance between HCV monoinfected and HCV/HIV coinfected groups for completion of treatment, SVR 12 or 24, and changes in fibrosis. Student t-test was used for continuous variables. For all statistical analyses, a 0.05 level of significance was used, and all p- values were two-sided. Statistical analysis was performed using GraphPad Prism, version 7.0d.

\section{Results}

\section{Study Population}

We identified $82 \mathrm{HCV}$ infected patients, $50 \%(\mathrm{n}=41)$ of which were coinfected with HIV (Figure 1). The overall median age was 60 years (Range, 32-73). Majority of the patients were African- American (68.3\%), and male $(59.5 \%)$. While age was not different by sex, it was different by race: African-Americans were, on average, 60.2 years (SD, 6.4), whites, 54 years (SD, 7.1), and other, 57 years (SD, 8.3), p<.0001.

\section{HCV Monoinfected versus HCV/HIV Coinfected Patients}

As seen in Table 1, the median HCV viral load in the monoinfected group was 2,961,050 IU/mL (range: 54,796-30,173,000) compared to the median HCV viral load in coinfected group that was $1,868,300 \mathrm{IU} / \mathrm{mL}$ with a range $19,610-48,999,970(\mathrm{p}=0.158)$. In the HCV/HIV coinfected group, most patients were virally suppressed with $97.5 \%$ of the patients with a viral load $<100$ copies/ $\mathrm{mL}$ and 1 patient with 370 copies $/ \mathrm{mL}$. Median CD4 count was $561 \mathrm{k} / \mu \mathrm{L}$ with a range (81-1421). Only 2 patients had CD4 $<200$ and both had undetectable HCV viral load at completion of therapy.

FibroSure ${ }^{\mathrm{TM}}$ results were divided as $<\mathrm{F} 2$ for mild fibrosis and $>\mathrm{F} 3$ for advanced fibrosis. In the monoinfected group, $49 \%$ had mild fibrosis and $51 \%$ had advanced fibrosis at baseline. Meanwhile, in the coinfected group, $41 \%$ had mild fibrosis and a higher percentage, $59 \%$ had advanced fibrosis $(\mathrm{p}=0.657)$. Regarding DAA regimens, $78 \%$ of the patients were treated with ledipasvir/sofosbuvir (see Table 2 ) as $67 \%$ of the patients had genotype 1a. Twelve percent of the patients in the monoinfected group were treatment experienced vs $15 \%$ in the coinfected group.

\section{SVR in HCV Monoinfected versus HCV/HIV Coinfected Patients}

From the 41 patients in the monoinfected group, data was collected from 27 patients (see Figure 1). Fourteen patients were not evaluated for SVR 12 or 24 as they lost follow up, but 13/14 patients were undetectable at either 4,8 or 12 weeks of treatment. From the 27 patients that followed up, $25(93 \%)$ achieved either SVR 12 or 24 . Two patients (7\%) had detectable viral load at completion of therapy. In the HIV/HCV coinfected group, data was obtained from 37 patients, 4 patients lost follow up. One patient didn't complete therapy but continued follow up. The 4 patients that lost follow up had undetectable viral load at either 4,8 or 12 weeks of treatment. The coinfected patient that didn't complete therapy had a $\mathrm{HCV}$ viral load of 252,590 IU/mL and achieved SVR after receiving 4 weeks of therapy. All $37(100 \%)$ patients in the coinfected group that followed up had documented SVR 12 or 24.

\section{Changes in Fibrosis in HCV Monoinfected versus HCV/HIV Coinfected}

In terms of fibrosis in the monoinfected group, FibroSure ${ }^{\mathrm{TM}}$ after SVR either at 12 or 24 weeks was collected from 18 patients. Twelve patients $(67 \%)$ demonstrated improvement in at least one METAVIR stage in FibroSure $^{\mathrm{TM}}$ and 6 (33\%) had no changes in FibroSure ${ }^{\mathrm{TM}}$. Worsening of fibrosis was not observed in the monoinfected group at either SVR 12 or 24 weeks. In the HIV/HCV coinfected group, FibroSure ${ }^{\mathrm{TM}}$ at either 12 or 24 weeks of completion of therapy was obtained in 16 patients. Eight patients $(50 \%)$ demonstrated improvement of fibrosis, $5(31 \%)$ had no changes in FibroSure ${ }^{\mathrm{TM}}$ stage and $3(19 \%)$ had worsening of fibrosis according to FibroSure ${ }^{\mathrm{TM}}$ stage (See Figure 2). The three patients that had worsening fibrosis were aa, males, 58 years or older with CD4

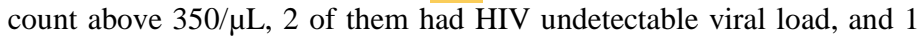
had 350 copies/mL. HCV viral load in these 3 patients ranged from

African-American 
2,743,110 - 5,294,540 IU/mL, and antiretroviral (ARV) regimen consisted of an integrase inhibitor (INSTI) and 2 nucleoside reverse

82 patients included
More space here between text and figure. It is confusing
41 HCV Monoinfected

9 lost follow up after completion of therapy

5 lost follow up before completion of therapy transcriptase inhibitors (NRTIs).
$41 \mathrm{HCV} / \mathrm{HIV}$ Coinfected

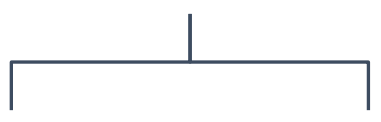

27 completed treatment and followed up for SVR 4 lost follow up after completion of therapy
36 completed therapy and followed up for SVR

1 did not complete therapy but achieve

Abbreviations: HCV, hepatitis c virus; HIV, human immunodeficiency virus.

achieved SVR

Figure 1: Patient flow chart of HCV monoinfected and HCV/HIV coinfected patients.

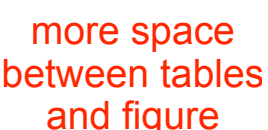

\begin{tabular}{|c|c|c|c|}
\hline Patient Characteristics & HCV monoinfected, $n=41$ & HCV/HIV coinfected, $n=41$ & $\mathrm{P}$ value \\
\hline Male sex $(\%)$ & $21(51)$ & $28(68)$ & .176 \\
\hline Age, median (range) & $60(32-71)$ & $60(47-73)$ & .652 \\
\hline Race: AA (\%) & $22(54)$ & $34(83)$ & \multirow{2}{*}{.008} \\
\hline White/other (\%) & $16 / 3(46)$ & $6 / 1(17)$ & \\
\hline ALT, IU/L median (range) & $53(10-399)$ & $38(8-183)$ & .131 \\
\hline 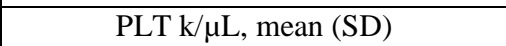 & $224.3(92.9)$ & $175.0(74.9)$ & .0098 \\
\hline HCV viral load, median (range),IU/ mL & $\begin{array}{c}2,961,050 \\
(54,796-30,173,000)\end{array}$ & $\begin{array}{c}1,262,530 \\
(19,610-48,999,970)\end{array}$ & .158 \\
\hline CD4 / $\mu \mathrm{L}$, median (range) & N/A & $561(81-1421)$ & $\mathrm{n} / \mathrm{a}$ \\
\hline $\begin{array}{c}\text { HIV viral load, copies/mL (\%) } \\
<20\end{array}$ & N/A & $33(80)$ & $\mathrm{n} / \mathrm{a}$ \\
\hline$>20<100$ & N/A & $7(17.5)$ & $\mathrm{n} / \mathrm{a}$ \\
\hline$>100$ & N/A & $1(2.5)$ & $\mathrm{n} / \mathrm{a}$ \\
\hline $\begin{array}{c}\text { FibroSure }^{\mathrm{TM}} \text { Baseline (\%) } \\
\leq \mathrm{F} 2\end{array}$ & $20(49)$ & $17(41)$ & \multirow[t]{2}{*}{.657} \\
\hline$\geq \mathrm{F} 3$ & $21(51)$ & $24(59)$ & \\
\hline
\end{tabular}

Abbreviations: AA, African American; ALT, alanine aminotransferase; HCV, hepatitis C virus; HIV, human immunodeficiency virus, PLT, platelets.

Table 1: Baseline Characteristics

\begin{tabular}{|c|c|c|c|c|c|c|}
\hline \multirow[t]{2}{*}{ DAA Regimens } & \multirow[t]{2}{*}{$\begin{array}{c}\text { Total } n=82 \\
(\%)\end{array}$} & \multicolumn{2}{|c|}{$\begin{array}{c}\text { HCV monoinfected, } \\
n=41(\%)\end{array}$} & \multicolumn{2}{|c|}{$\begin{array}{c}\text { HCV/HIV coinfected, } \\
n=41(\%)\end{array}$} & \multirow[t]{2}{*}{$P$ value } \\
\hline & & Total & Genotype & Total & Genotype & \\
\hline $\mathrm{LDV} / \mathrm{SOF}$ & $64(78)$ & $31(76)$ & $\begin{array}{c}1 a-27(65.8) \\
1 b-3(7.3) \\
4-1(2.4)\end{array}$ & $33(80)$ & $\begin{array}{c}1 a-28(68.2) \\
1 b-4(10) \\
4-1(2.4)\end{array}$ & \multirow[b]{2}{*}{0.79} \\
\hline Other Regimens & $18(22)$ & $10(24)$ & $\begin{array}{c}1 \mathrm{a}-4(10) \\
1 \mathrm{~b}-2(4.8) \\
2-3(7.3) \\
3-1(2.4)\end{array}$ & $8(20)$ & $\begin{array}{l}1 \mathrm{a}-3(7.3) \\
1 \mathrm{~b}-3(7.3) \\
2-2(4.8)\end{array}$ & \\
\hline $\begin{array}{c}\text { Treatment Experienced } \\
(\%) \mathrm{Y}\end{array}$ & 11(14) & \multicolumn{2}{|r|}{$5(12)$} & \multicolumn{2}{|c|}{$6(15)$} & \multirow[t]{2}{*}{1.0} \\
\hline $\mathrm{N}$ & $71(86)$ & & $6(88)$ & & $85)$ & \\
\hline
\end{tabular}

Abbreviations: DAA, direct acting antiviral; HCV, hepatitis C virus; HIV, human immunodeficiency virus; LDV, ledipasvir; SOF, sofosbuvir.

Table 2: DAA Regimens and HCV Genotypes 


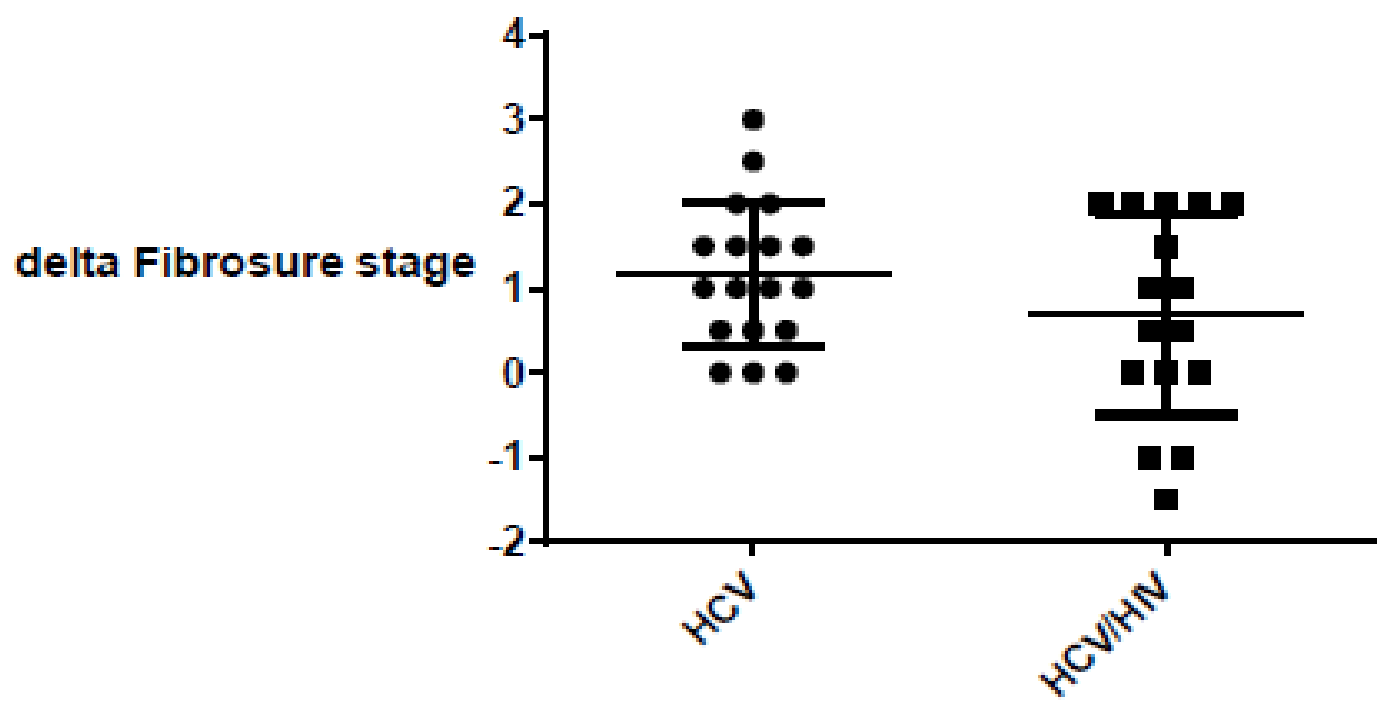

Figure 2: Delta FibroSure ${ }^{\mathrm{TM}}$ Stage in HCV Monoinfected vs HCV/HIV Coinfected Patients

\section{Discussion:}

This small cohort provides real world data about the efficacy of DAAs in HCV monoinfected, but more importantly, in HCV/HIV coinfected patients. In previous clinical trials where HCV monoinfected patients were treated with interferon-based and ribavirin therapy, SVR rates ranged from $35 \%$ to $50 \%$ in genotypes 1 or 4 , and up to $80 \%$ in genotypes 2 or 3. $[14,15]$ These regimens were associated with increased costs, poor tolerability, and adverse effects. [11, 12] In HCV/HIV coinfected patients, poorer responses were documented and higher rates of adverse effects were observed. [16,19] Not only low SVR rates, but also progression of HCV-related liver damage including fibrosis became a major area of concern, especially in the era prior to DAAs. Factors that contribute to worsening prognosis besides HIV seropositivity include alcohol consumption, older age at the time of HCV infection, and CD4 count < 200 cells $/ \mathrm{mm}^{3}$, which are also associated with a higher rate of fibrosis progression. [20,22]

In this study, HCV/HIV coinfected patients treated with DAAs demonstrated higher SVR rates than HCV monoinfected patients with overall well tolerability. Our study correlates with multiple other studies where coinfected patients, in real world setting achieved high SVR rates. Del Bello, et al published data with sofosbuvir containing regimens in which coinfected patients achieved high SVR rates with minimal adverse effects. SVR rates in coinfected patients did not vary with ARV regimen used. [23] In ALLY-2 study, SVR 12 was achieved in 97\% or more patients receiving any ARV regimen. [24] The ION 4 study with coinfected patients documented high rates of sustained virologic response that ranged from 96 to $100 \%$. [25] In the PHOTON-1 trial, $67-88 \%$ of treatment-naive participants achieved SVR12, while among treatmentexperienced participants, 92-94\% achieved SVR12. [26] In our study, 11 patients were treatment experienced, and all of them achieved SVR at 12 or 24 independently of HIV coinfection.

More patients in the monoinfected group did not attend all of the scheduled appointments as compared with the coinfected group. In the HCV monoinfected group, 25 (93\%) achieved either SVR 12 or 24 . Two patients were non-compliant and had detectable viral load on evaluation at week 12. In the HCV/HIV coinfected group, 37 patients achieved SVR, while interestingly one patient in the HCV/HIV coinfected group received only 4 weeks of therapy but had undetectable viral load 4 weeks and remained undetectable to date.

Other studies have shown different results due to poor compliance in HIV coinfected patients. Lakshmi et al concluded that real world HCV cure rates with DAAs in HCV/HIV coinfection were lower than those seen in clinical trials. In their patients, cure was associated with attendance to follow up clinic visits and use of an integrase inhibitor based HIV regimen. Cure was achieved in $83.3 \%$. [27] In our study, more HCV/HIV coinfected patients completed therapy and followed up (88\% vs. $66 \%$, respectively) and achieved SVR rates compared to monoinfected patients ( $88 \%$ vs $61 \%$ ). We feel that this phenomenon is due to coinfected patients being already engaged in HIV care through Ryan White Program.

Before DAAs era, African-Americans had poorer response rates to pegylated interferon and ribavirin compared to Caucasians (28\% vs 52\%, respectively). [28,30] For this reason, AA patients with HCV/HIV coinfection were associated with a lower likelihood of receiving treatment for HCV. [31] In our clinic population, the AA population with HCV/HIV coinfection comprises a higher number than Caucasians. Compared to the mono-infected group, the co- infected population was composed of more AAs. In terms of ARV therapy, an INSTI with NRTI backbone was the most common regimen used due to safety and less drug-drug interactions (see Appendix Tables 3 and4).

\begin{tabular}{|c|c|}
\hline ART Regimen & SOF/LDV N=33 (\%) \\
\hline RPV/FTC/TDF & $5(15)$ \\
\hline NVP/ABC/3TC & $1(3)$ \\
\hline ATV/ABC/3TC & $1(3)$ \\
\hline DRV/c/FTC/TDF & $1(3)$ \\
\hline DRV/r/INSTI & $3(9)$ \\
\hline INSTI/NRTI/ NRTI & $22(67)$ \\
\hline
\end{tabular}

Abbreviations: $A B C$, abacavir; ART, antiretroviral therapy; ATV, atazanavir; c, cobicistat; DRV/r, darunavir/ritonavir; FTC, Emtricitabine; INSTI, integrase strand transfer inhibitors; LDV, ledipasvir; NRTI, nucleoside reverse transcriptase inhibitor, NVP, nevirapine; RPV, rilpivirine SOF, sofosbuvir; TDF, tenofovir disoproxil fumarate; VEL, velpatasvir; 3TC, lamivudine

Table 3: SOF/LDV and ART Regimens

Can lower the table to have more space between text and table 


\begin{tabular}{|c|c|c|c|c|c|}
\hline DAA Regimen & Total $n=8$ & NRTI & NNR TI & PI & INSTI \\
\hline $\mathrm{LDV} / \mathrm{SOF} / \mathrm{RBV}$ & 0 & 0 & 0 & 0 & 0 \\
\hline VEL/SOF/ RBV & 1 & FTC/ TDF & RPV & 0 & 0 \\
\hline PrOD/RBV & 2 & FTC/ TDF & 0 & 0 & DTG, RAL \\
\hline $\mathrm{DCV} / \mathrm{SOF}$ & 1 & $\mathrm{ABC} / 3 \mathrm{TC}$ & 0 & 0 & DTG \\
\hline SOF/RBV & 1 & 0 & 0 & $\begin{array}{c}\text { DRV } \\
/ \mathrm{r}\end{array}$ & DTG \\
\hline $\mathrm{DCV} / \mathrm{SOF} / \mathrm{RBV}$ & 1 & FTC/ TDF & EFV & 0 & 0 \\
\hline PrOD & 1 & FTC/ TDF & 0 & 0 & RAL \\
\hline VEL/SOF & 0 & 0 & 0 & 0 & 0 \\
\hline EBV/GZR & 1 & $\mathrm{ABC} / 3 \mathrm{TC}$ & 0 & 0 & DTG \\
\hline
\end{tabular}

Abbreviations: ABC, abacavir; ART, antiretroviral therapy; ATV, atazanavir; DAA, direct acting antiviral; DCV, daclatasvir; DRV/r, darunavir/ritonavir; DTG, dolutegravir; EBV, elbasvir; EFV, efavirenz; FTC, Emtricitabine; GZR, grazoprevir; INSTI, integrase strand transfer inhibitors; LDV, ledipasvir; NNRTI, non-nucleoside reverse transcriptase inhibitor; NRTI, nucleoside reverse transcriptase inhibitor; PI, protease inhibitor; PrOD, ombitasvir/paritaprevir/ritonavir/ dasabuvir; RAL, raltegravir, RBV, ribavirin; RPV, rilpivirine SOF, sofosbuvir; TDF, tenofovir disoproxil fumarate, VEL, velpatasvir; 3TC, lamivudine.

Table 4: Other DAAs and ART

\begin{tabular}{|c|c|c|c|c|c|}
\hline \multirow{2}{*}{$\begin{array}{c}\text { DAA Regimens Other } \\
\text { than LDV/ SOF } \\
(\%)\end{array}$} & \multirow[t]{2}{*}{ Tota I $(n=18)$} & \multicolumn{2}{|c|}{ HCV monoinfected, $n=10$} & \multicolumn{2}{|c|}{ HIV/HCV coinfected, $n=8$} \\
\hline & & Total & Genoty pe & Total & Genoty pe \\
\hline LDV/SOF/ RBV & 1 & $1(2.4)$ & $1 \mathrm{a}$ & $0(0)$ & N/A \\
\hline VEL/SOF/ RBV & 1 & $0(0)$ & N/A & $1(2.5)$ & $1 \mathrm{a}$ \\
\hline $\mathrm{PrOD} / \mathrm{RBV}$ & 4 & $2(4.8)$ & $1 \mathrm{a}$ & $2(5)$ & $1 \mathrm{a}, 1 \mathrm{~b}$ \\
\hline $\mathrm{DCV} / \mathrm{SOF}$ & 2 & $1(2.4)$ & 3 & $1(2.5)$ & 2 \\
\hline SOF/RBV & 3 & $2(4.8)$ & 2,3 & $1(2.5)$ & 2 \\
\hline $\mathrm{DCV} / \mathrm{SOF} / \mathrm{RBV}$ & 1 & $0(0)$ & N/A & $1(2.5)$ & $1 \mathrm{a}$ \\
\hline PrOD & 3 & $2(4.8)$ & $1 \mathrm{~b}$ & $1(2.5)$ & $1 \mathrm{~b}$ \\
\hline VEL/SOF & 1 & $1(2.4)$ & 2 & $0(0)$ & N/A \\
\hline EBV/GZR & 2 & $1(2.4)$ & 2 & $1(2.5)$ & N/A \\
\hline
\end{tabular}

Abbreviations: DAA, direct acting antiviral; DCV, daclatasvir; EBV, elbasvir; GZR, grazoprevir; LDV, HCV, hepatitis c virus; HIV, human immunodeficiency virus; ledipasvir; PrOD, ombitasvir/ paritaprevir/ritonavir/dasabuvir; RBV, ribavirin; SOF, sofosbuvir; VEL, velpatasvir.

Table 5: DAA Regimens other than LDV/SOF and Genotypes

As SVR is considered the first step in decreasing morbidity and mortality in HCV infected individuals, assessment and monitoring of fibrosis after achieving SVR is an interesting field of investigation. It is known that HIV enhances liver damage progression and worsening fibrosis with more aggressive course of liver disease in coinfected patients. As DAAs have only recently become available, there is not enough data about the effects of SVR on liver fibrosis years after treatmenst. In a study on changes in fibrosis, Martinez et al compared liver fibrosis before and after antiviral therapy by different serum marker panels in patients with chronic hepatitis $\mathrm{C}$ using the Enhanced Liver Fibrosis (ELF) score. In the study, the ELF score decreased significantly in patients with SVR but remained unchanged in non-responders. A decrease in ELF score after antiviral treatment reflects the impact of viral clearance in hepatic extracellular matrix and probably in the improvement of liver fibrosis. [32]

Another study evaluated ELF scores and FibroScan ${ }^{\circledR}$ in $32 \mathrm{HCV}$ infected patients in Germany treated with SOF (93.8\% SVR12). The study found biochemical response within 4 weeks and significant decrease from baseline to 12-week post-treatment follow-up in ELF and
FibroScan ${ }^{\circledR}$ measurements, indicating improvement of the dynamics of liver fibrosis. [33] In our study, at SVR 12 or 24 weeks, at least $50 \%$ of patients in both groups demonstrated improvement in liver fibrosis defined as one Metavir stage improvement based on FibroSure ${ }^{\mathrm{TM}}$ stages. More patients in the monoinfected group demonstrated improvement in fibrosis although not statistically significant. There was no worsening fibrosis in the monoinfected patients compared to a $19 \%$ in the coinfected group possibly due to the effect of HIV on liver fibrosis despite viral suppression or antiretroviral therapy. Two of the coinfected patients with worsening fibrosis had undetectable HIV viral load, while the patient that had 1.5 worsening fibrosis, had 370 copies $/ \mathrm{mL}$. This is consistent with a study that showed accelerated fibrosis in HIV coinfected patients even if HIV replication is under control by ARVs. [8] As newer and better DAAs become available, and more data on SVR and liver fibrosis becomes available, further studies with larger sample size would be needed to study long-term effects of SVR on liver fibrosis in this population. 
Our study has many limitations. Small sample size could skew the results that we have demonstrated here in larger studies. Use of certain hepatotoxic substances including over the counter medications, routine medications and alcohol could contribute to worsening of fibrosis, but we were unable to take these into account. We did not routinely obtain serum alcohol levels to know if participants used alcohol regularly. FibroSure ${ }^{\mathrm{TM}}$ as a biomarker has its limitations when compared to elastography or biopsy for the assessment of fibrosis. As assessment of fibrosis after HCV treatment is not part of the American Association for the Study of Liver Disease (ASSLD) guidelines, not all patients had the opportunity to obtain a FibroSure ${ }^{\mathrm{TM}}$ at 12 or 24 weeks after completion of therapy due to limited economic resources.

\section{Conflict of interest:}

Dora Lebron, MD - none

Manal Elnabtity, PharmD - none

Alexandra Stang, MD - none

Ahmed Hamed, MD - none

Alicia Lagasca, MD - none

Marysia Grzybowski - none

Rabindra Ghimire, MD - none

Dawd Siraj, MD - not known

Paul Cook, MD - PI for Gilead, Affinergy, Leonard-Meron Biosciences

No financial support

\section{Authors Contribution:}

Dora Lebron - corresponding author

Manal Elnabtity - data curation

Alexandra Stang - data curation

Ahmed Hamed - data curation

Alicia Lagasca - supervising

Marysia Grzybowski - statistics

Rabindra Ghimire - supervising, editing

Dawd Siraj - supervising

Paul Cook - supervising, editing

\section{References:}

1. Micallef JM, Kaldor JM, and Dore GJ. (2006) Spontaneous viral clearance following acute hepatitis $\mathrm{C}$ infection: a systematic review of longitudinal studies. Journal of Viral Hepatitis, 13 (1):34-41.

2. Mohamed AA, Elbedewy TA, El-Serafy M, El-Toukhy N, Ahmed W, Ali El Din Z. (2015) Hepatitis C virus: A global view. World Journal of Hepatology.7 (26):2676-2680.

3. Zignego AL, Giannini C, Ferri C. (2007) Hepatitis C virusrelated lymphoproliferative disorders: An overview. World Journal of Gastroenterology: WJG.13 (17):2467-2478.

4. Calvaruso V, Craxì A. (2013) Immunological alterations in hepatitis $\mathrm{C}$ virus infection. World Journal of Gastroenterology: WJG.19 (47):8916-8923.

5. Kedia S, Bhatt VR, Rajan SK, Tandra PK, El Behery RA, Akhtari M. Benign and Malignant Hematological Manifestations of Chronic Hepatitis C Virus Infection. International Journal of Preventive Medicine. 2014;5(Suppl 3):S179-S192.

6. Reau N, Vekeman F, Wu E, Bao Y, Gonzalez YS. (2017) Prevalence and economic burden of extrahepatic manifestations of hepatitis $C$ virus are underestimated but can be improved with therapy. Hepatology Communications. 1 (5):439-452.

7. Behzadpour D, Ahmadi Vasmehjani A, Mousavi Nasab SD, Ahmadi NA, Baharlou R. (2016) Impact of HIV infection in patients infected with chronic HCV (genotypes 1a and 3a): virological and clinical changes. Pathogens and Global Health. 110(7-8):310-315.
8. Mastroianni CM, Lichtner M, Mascia C, Zuccalà $\mathrm{P}$, Vullo V. (2014) Molecular Mechanisms of Liver Fibrosis in HIV/HCV Coinfection. International Journal of Molecular Sciences.15 (6):9184-9208.

9. Chen JY, Feeney ER, Chung RT. (2014) HCV and HIV Coinfection: Mechanisms and Management. Nature reviews Gastroenterology \& hepatology. 11(6):362-371.

10. Holmes JA, Thompson AJ. (2015) Interferon-free combination therapies for the treatment of hepatitis C: current insights. Hepatic Medicine: Evidence and Research. 7:51-70.

11. Avidan NU, Goldstein D, Rozenberg L, et al. (2009) Hepatitis C Viral Kinetics During Treatment With Peg IFN-alpha-2b in HIV/HCV Co-Infected Patients as a Function of Baseline CD4+ $\mathrm{T}$ Cell Counts. Journal of acquired immune deficiency syndromes (1999). 52(4):452-458.

12. Sherman KE, Rouster SD, Stanford S, et al. (2010) HCV Quasispecies Complexity and Selection in HCV/HIV Coinfected Subjects Treated with Interferon-Based Regimens. The Journal of Infectious Diseases. 201(5): 712-719.

13. Meissner EG. (2017) Update in HIV/HCV Co-Infection in the Direct Acting Antiviral Era. Current opinion in gastroenterology. 33(3): 120-127.

14. Fried MW, Shiffman ML, Reddy KR,et al. (2002) Peginterferon alfa-2a plus ribavirin for chronic hepatitis $\mathrm{C}$ virus infection. $\mathrm{N}$ Engl J Med. Sep 26; 347(13): 975-982.

15. Manns MP, McHutchison JG, Gordon SC, et al. (2001) Peginterferon alfa- $2 b$ plus ribavirin compared with interferon alfa-2b plus ribavirin for initial treatment of chronic hepatitis $C$ : a randomised trial. Lancet. Sep 22; 358(9286): 958-965

16. Coppola N, Martini S, Pisaturo M, Sagnelli C, Filippini P, Sagnelli E. (2015) Treatment of chronic hepatitis $C$ in patients with HIV/HCV coinfection. World Journal of Virology.4(1):1-12

17. Italian Association for the Study of the Liver. (2010) Italian Society of Infectious, Tropical Diseases. Italian Society for the Study of Sexually Transmitted Diseases. Practice guidelines for the treatment of hepatitis $\mathrm{C}$ : recommendations from an AISF/SIMIT/ SIMAST Expert Opinion Meeting. Dig Liver Dis. Feb; 42(2): 81-91.

18. Rodriguez-Torres M, Slim J, Bhatti L, et al. (2012) Peginterferon alfa-2a plus ribavirin for HIV- HCV genotype 1 coinfected patients: a randomized international trial. HIV Clin Trials. 13: $142-152$.

19. Mehta SH, Lucas GM, Mirel LB, Torbenson M, Higgins Y, Moore RD, Thomas DL, Sulkowski MS. (2006) Limited effectiveness of antiviral treatment for hepatitis $\mathrm{C}$ in an urban HIV clinic. AIDS. 20:2361-2369.

20. Sherman KE, Rouster SD, Chung RT,Rajicic N. (2002) Hepatitis C Virus prevalence among patients infected with Human Immunodeficiency Virus: a cross-sectional analysis of the US adult AIDS Clinical Trials Group. Clin Infect Dis.34:831-837.

21. Bhattacharya R, Shuhart MC, et al. (2003) Hepatitis C and alcohol: interactions, outcomes, and implications. J Clin Gastroenterol. Mar; 36(3): 242-252.

22. Poynard T, Bedossa P, Opolon P.(1997) Natural history of liver fibrosis progression in patients with chronic hepatitis $\mathrm{C}$. The OBSVIRC, METAVIR, CLINIVIR, and DOSVIRC groups. Lancet. Mar 22; 349(9055): 825-832

23. Del Bello D, Cha A, Sorbera M, et al. (2016) Real-World Sustained Virologic Response Rates of Sofosbuvir-Containing Regimens in Patients Coinfected With Hepatitis C and HIV, Clinical Infectious Diseases, Volume 62, Issue 12, 15 June, Pages 1497-1504

24. Luetkemeyer AF, McDonald C, Ramgopal M, et al. (2016) Clin 
Infect Dis. Jun 15; 62(12):1489-1496

25. Naggie S, Cooper C, Saag M, et al. (2015) Ledipasvir and Sofosbuvir for HCV Patients Coinfected with HIV-1. N Engl J Med. Aug 20;373(8):705-713

26. Sulkowski MS, Naggie S, Lalezari J, et al. (2014) Sofosbuvir and ribavirin for hepatitis $\mathrm{C}$ in patients with HIV coinfection. JAMA. Jul 23-30;312(4):353-361

27. Lakshmi S, Alcaide M, Palacio AM, et al. (2016) Improving HCV cure rates in HIV coinfected patients-A real world perspective. The American journal of managed care.22 (6 Spec No):SP198-SP204.

28. Silver D, Karnik G, Osinusi A, et al. (2013) Effect of HIV on Liver Fibrosis Among HCV- Infected African Americans. Clinical Infectious Diseases: An Official Publication of the Infectious Diseases Society of America.56 (9):1280-1283.

29. Sterling RK SR, Luketic VA, Sanyal AJ, et al. (2004) A comparison of the spectrum of chronic hepatitis $\mathrm{C}$ virus between Caucasians and African Americans. Clin Gastroenterol
Hepatol.2:469-473.

30. Conjeevaram HS, Fried MW, Jeffers LJ, et al. (2006) Peginterferon and ribavirin treatment in African American and Caucasian American patients with hepatitis $\mathrm{C}$ genotype Gastroenterology.131:470-477.

31. Butt AA, Tsevat J, Leonard AC, et al. (2009) Effect of race and HIV co-infection upon treatment prescription for hepatitis $C$ virus. International journal of infectious diseases: IJID: official publication of the International Society for Infectious Diseases. 13 (4): 449-455.

32. Martinez, et al. (2011) Assessment of liver fibrosis before and after antiviral therapy by different serum marker panels in patients with chronic hepatitis C. Aliment Pharmacol Ther. Jan; 33(1):138-148.

33. Bernuth et al. (2016) Early changes in dynamic biomarkers of liver fibrosis in hepatitis C virus- infected patients treated with sofosbuvir. Dig Liver Dis. Mar; 48(3):291-297. work is licensed under Creative Attribution 4.0 License

To Submit Your Article Click Here: Submit Article

DOI: $10.31579 / 2690-4861 / 036$
Ready to submit your research? Choose Auctores and benefit from:

* fast, convenient online submission

* rigorous peer review by experienced research in your field

* rapid publication on acceptance

* authors retain copyrights

* unique DOI for all articles

* immediate, unrestricted online access

At Auctores, research is always in progress.

Learn more https://www.auctoresonline.org/journals/internationaljournal-of-clinical-case-reports-and-reviews 